\title{
THE MANGROVE ECOSYSTEM POTENTIAL FOR EDUCATIONAL TOUR DEVELOPMENT AROUND POND EDUCATION OF HASANUDDIN UNIVERSITY (UNHAS) IN MALLUSETASI DISTRICT, BARRU REGENCY.
}

\author{
Amran Saru ${ }^{1}$, Rijal Idrus ${ }^{2}$, Muh. Ilham ${ }^{3}$ \\ Received: August 20, 2019, Approved: October 25, 2019
}

1,2,3 Department of Marine Science, Faculty of Marine Science and Fisheries, University of Hasanuddin.

Jl. Perintis Kemerdekaan Km. 10 Tamalanrea, Makassar, 90245

Corresponding Author:

Amran Saru

Email: amransaruprof@gmail.com

\begin{abstract}
This research was conducted in October 2017. The research location was the Hasanuddin University Education Pond, Bojo Village, Mallusetasi District, Barru Regency. The objectives of this study were: (a) To identify the various types of mangroves that make up the educational field in the Hasanuddin University Education Pond; (b) To Identify and to recognize the organisms associated with various types of mangroves that compose educational sites on the coast of the UNHAS Education Pond, and (c) To analyze data and information related to mangrove ecosystems and their associated organisms for the suitability of Education. Mangrove data collection using transect (Line transect) with $10 \mathrm{x} 10$ meters plot area, while collecting macrozoobenthos data using a scope and sieve net, while observing other parameters at the five stations with three replications carried out based on instructions (Englis, at.al., 1994; Noor, et al., 1999; Saru, 2013; and Bahar, et al., 2015). The results showed that 3 mangrove families were identified, namely Avicenniaceae, Rhizophoraceae, and Sonneratiaceae consisting of 7 species of mangrove, namely: Avicennia marina, Bruguiera gymnorhiza, Ceriops decandra, Rhizophora apiculata, R. mucronata, R. stylosa, and Soneratia alba. While the associated organisms, namely: 3 species for Carustacea, 4 species for Fish, 7 species for Mollusca, 3 species for Bird and 1 species for Reptile. Based on the results of land suitability analysis showed that the ecosystem of mangrove in Hasanuddin University Education Pond included in the conditional category for the development of Mangrove Education tour.
\end{abstract}

Keywords: Mangrove Ecosystem, Education Tour Development, UNHAS Education Pond.

\section{INTRODUCTION}

Barru Regency has a coastline length around 18,055 meters or $18 \mathrm{~km}$, most of which are covered with mangroves with an area of about 113.02 ha, including in Mallusetasi District, there are around $3.16 \%$ of the total mangrove area growing on the coast of Barru Regency, while the width area in Bojo Village is around 3.25 ha or around the location of the Unhas Education Pond (Saru, 2013 and Iham, 2018). Mangrove ecosystems can contribute positively to controlling the pace of global climate change and ecological dynamics of an ecosystem, in addition mangrove ecosystems also has functions as ecological stability or balance of ecosystems, nutrient sources, as nursery areas, feeding ground areas, and spawning ground. The important role of the mangrove ecosystem indicates that the mangrove ecosystem needs special attention, so as to avoid damage both naturally and anthropogenic-ally, including visitors of educational tour activities.

Based on the initial survey results in the UNHAS Education Pond area, especially in the mangrove area or we call educational tour activities with the name "Crab Park Indonesia -Hasanuddin University Education Park". This educational tour activity is a partnership between Faculty of Marine Science and Fisheries (FIKP) of Hasanuddin University and the private sector, this is done to optimize the UNHAS assets. One of the educational tour activities that is very related to the mangrove ecosystem, namely installation of Titian or Tracking in the mangrove area, this activity aimed to pamper visitors to learn directly to nature through direct monitoring of the Mangrove Ecosystem and its associated Organisms.

The existence of the educational tour activity is thought to trigger two possible changes in the mangrove ecosystem, namely: (1) good environmental monitoring and management, especially the mangrove ecosystem by the educational manager, so that the mangrove can develop properly, the density, composition of species and the size of the area increases, including associated organisms; (2) inadequate supervision and management of the environment that causes damage to mangrove ecosystems. If this happens then the Mangrove Ecosystem is degraded, the density, species composition and the width area will be reduced, including the decrease in associated organisms. Therefore it is necessary to do research on How the Potential of Mangrove Ecosystems for Educational Development around the Unhas Educational Pond in Mallusetasi District, Barru Regency. The purpose of this research were: (a) Identifying various types of mangroves that grow or arrange educational activities in the coastal areas of UNHAS Education Pond; (b) Identifying and recognizing organisms or macrozoobenthos associated with various types of mangroves that compose educational tour sites on the coast of the UNHAS Education Pond, and (c) Analyzing data and information related to mangroves 
with macrozoobenthos using ecological analysis methods.

\section{MATERIALS AND METHODS}

This research was carried out in August - October 2017. The research was conducted at the Hasanuddin University Education Pond, Bojo Village, Mallusetasi District, Barru Regency (Figure 1). Mangrove samples analysis, organisms and environmental parameters were carried out at the Marine Ecology Laboratory and the Physics and Geomorphology Oceanography Laboratory, Department of Marine Sciences, Faculty of Marine Sciences and Fisheries, Hasanuddin University.

The equipments used in this research were GPS, stationary, digital cameras, compasses, roll meters, raffia ropes, $\mathrm{pH}$ meters, Handrefractometers, thermometers, scale poles, scopes, paralon pipes, cool boxes, sieve nets, markers, and boats, fishing gear 2 inch mesh size gill nets, label paper, markers and tissue. While the materials used in this research including identification sheets and a guide to the mangroves introduction in Indonesia (Noor et al., 2006), fish identification books, macrozoobenthos identification books (Darma, 1988; Darma, 1992; Colin and Arneson, 1995).

\section{Determination of Research Station}

Determination of the station is based on the presence of mangrove species that grow around the research site. The principle of determining this station is based on the representation of the existence of mangroves, where there are 5 stations consisting of 3 replications, each repetition has a number of plots that are adjusted to the thickness of the mangrove.

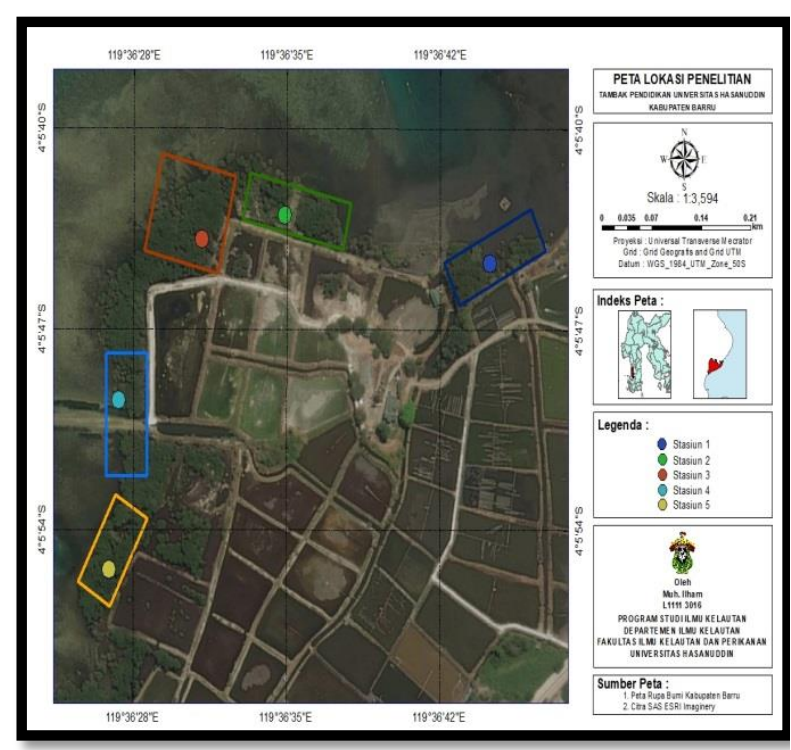

Figure 1. Research location Map, Pannikiang Island in Barru Regency

\section{Measurement of Research Parameters}

The mangrove data measurement was carried out using the transect method (line transect), which is to draw lines drawn perpendicularly from the coastline to the station that is adjusted to the extent of the mangrove species growing. Each transect that has been formed at each observation station, in which a $10 \times 10(\mathrm{~m})$ plot is made for the tree level, mangrove thickness is measured manually using a roll meter that is drawn perpendicular to the coastline starting from the mangrove forest at the sea boundary to the landline (English et al., 1994). Identify the names of mangrove species that were not yet known or by taking parts or pieces from branches, complete with flowers and leaves and were identified based on the mangrove identification book (Noor, 1999). Next, count the mangrove species number and measure the mangrove tree diameter where for the category of trees are woody plants with $\geq 4 \mathrm{~cm}$ diameter (Bahar et al., 2015).

Mollusca, Crustacean and water quality samples were taken at each station that was determined, simultaneously based on the procedure: (1) Mollusca and Crustaceans, sampled using a trowel, samples containing macrozoobenthos mixed with sediment were separated by using sieve net, macrozoobentos samples inserted into the in a labeled sample bag, preserved with alcohol and subsequently identified in the laboratory. Sampling was performed 3 times for each observation station. Measuring the supporting variables such as: Temperature, salinity, $\mathrm{pH}$, and basic sediments are carried out simultaneously with the taking of the main variables at each observation station; (2) Identification of Macrozoobenthos Samples, based on manuals: Colin and Arneson (1995), Dharma (1988), Dharma (1992), Gem (1984), Mapstone (1990), Sabelli (1982).

\section{Data analysis}

Mangrove data obtained from the field were then analyzed to determine the density of type $\mathrm{i}(\mathrm{Di})$ and closure of type i (Ci) (Bengen, 2002 and Kusmana, 1997). The mangroves condition is based on the standard of mangrove density and closure based on the Minister of the Environment Number 201 of 2004. Whereas macrozoobnetos were analyzed using the Shannon Wienner Formula in (Odum, 1971), to find out: the abundant species (K), diversity ( $\left.\mathrm{H}^{\prime}\right)$, uniformity (E) and dominance (D). Furthermore, to determine the condition of the mangrove ecosystem at the research site, the Ecological Index was used (Odum, 1971; Whtter, 1987 and Naughton, 1990).

\section{RESULTS AND DISCUSSION}

\section{Overview of Research Locations}

UNHAS Education Pond Area consists of fishpond areas and there are 2 parts of the fish hatchery area. 
The distance of fish hatchery is about $500 \mathrm{~m}$ from the pond. Both fish and shrimp hatcheries are located on the coast and the Makassar - Pare-Pare axis road. The distance between the two hatcheries is around $80 \mathrm{~m}$, the UNHAS education pond has an area of 212,550 $\mathrm{m}^{2}$, located in Bojo Village, Mallusetasi District, Barru Regency. The boundaries are as follows: North is bordered by the Sea, East is bordered by the Makassar-Pare-Pare Road, South is bordered by Pond, West is bordered by the Makassar Strait, as shown on the location map (Figure 2). UNHAS Education Pond with a height of about 2 meters above sea level and an area of $20.63 \mathrm{ha} / \mathrm{m}^{2}$, has a wide enough rice fields, with a distance to the district capital $\pm 1.00 \mathrm{~km}$, and distance to the regency capital $\pm 35.00 \mathrm{~km}$ and distance to the provincial capital $\pm 115 \mathrm{~km}$. The total population of Bojo Village is 3,564 people.

\section{Mangrove Conditions}

Based on the results of research and measurements of the thickness of mangrove ecosystems of each station from the coastline to the land carried out in the UNHAS Education Pond Area obtained results at each station, namely: Station I had an average thickness of mangrove $47.67 \mathrm{~m}$, Station II, the average mangrove thickness was $31.67 \mathrm{~m}$, Station III had an average thickness of mangrove $46.33 \mathrm{~m}$, an average thickness of mangrove in Station IV was $41.33 \mathrm{~m}$ and Station V had an average thickness of mangrove $53.00 \mathrm{~m}$. This explains that the highest thickness was found in station V compared to Station I, II, III and IV. Based on mangrove thickness parameters (Ministry of Environment Decree no. 21 of 2014 and Yulianda, 2007), the categories for stations I, II, III, IV were bad for mangrove tourism because they were less than 50 m. Mangrove ecosystems in the UNHAS Educational Pond Area are not yet well known by tourists, both local and long distance. Although a wooden bridge facility (trail) has been built for visitors can enjoy the mangrove forest in UNHAS Educational Pond area. This bridge is not yet a good enough reason for visitors to enjoy the condition of mangrove forests that are quite thick.

\section{Mangrove Type Composition}

Based on the identification results carried out in the field, 3 mangrove Families were found, namely Avicenniaceae, Rhizophoraceae, and Sonneratiaceae. Species identified include: Avicennia marina, Bruguiera gymnorhiza, Ceriops decandra, Rhizophora apiculata, R. mucronata, R. stylosa, Soneratia alba. Data on the types of mangroves found in the UNHAS Education Ponds area are presented in Table 1.
Table 1. Composition of mangrove species found in the UNHAS Education Pond Area

\begin{tabular}{|c|c|c|}
\hline Station & Mangrove Typpes & $\begin{array}{l}\text { Average } \\
\text { (m2) }\end{array}$ \\
\hline \multirow{4}{*}{ I } & Avicennia marina & 1,00 \\
\hline & Rhizophora stylosa & 1,50 \\
\hline & Sonneratia alba & 2,00 \\
\hline & Rhizophora apiculata & 3,20 \\
\hline \multirow{5}{*}{ II } & Rhizophora apiculata & 3,00 \\
\hline & Bruguiera gymnorhiza & 4,00 \\
\hline & Ceriops decandra & 4,00 \\
\hline & Rhizophora stylosa & 6,67 \\
\hline & Sonneratia alba & 11,00 \\
\hline \multirow{5}{*}{ III } & Sonneratia alba & 1,00 \\
\hline & Bruguiera gymnorhiza & 2,50 \\
\hline & Rhizophora apiculata & 7,50 \\
\hline & Rhizophora mucronata & 8,00 \\
\hline & Rhizophora stylosa & 9,00 \\
\hline \multirow{3}{*}{ IV } & Sonneratia alba & 1,50 \\
\hline & Rhizophora apiculata & 2,50 \\
\hline & Rhizophora stylosa & 7,67 \\
\hline $\mathrm{V}$ & Rhizophora stylosa & 8,42 \\
\hline
\end{tabular}

Table 1 shows that at station $\mathrm{i}$ there were 4 species namely Avicennia Marina, Rhizophora Apiculata, Rhizophora Stylosa and Sonneratia Alba. Station II there were 5 species namely Bruguiera Gymnorhiza, Ceriops Decandra, Rhizophora Apiculata, Rhizophora Stylosa and Sonneratia Alba. Station III had 5 species namely Bruguiera Gymnorhiza, Rhizophora Apiculata, Rhizophora Mucronata, Rhizophora Stylosa, Sonneratia Alba. Station IV had 3 species namely Rhizophora Apiculata, Rhizophora Stylosa and Sonneratia Alba. Station V had 1 species, namely Rhizophora Stylosa. Based on the parameters of mangrove types (yulianda, 2007), the categories for stations I, II, III and IV were quite good because the number of species was between $3-5$, while station $\mathrm{V}$ was not good because the number of species was only one. The numbers of mangrove species in this area were the result of mangrove rehabilitation done by students who were conducting the field practices and managers of UNHAS Education Ponds in collaboration with surrounding communities and become a potential for mangrove education tour in attracting the attention of tourists and researchers.

\section{Mangrove Species Density}

Species density is the number of stands of a species in one unit area (Bengen, 2004). The density value of mangrove vegetation in the UNHAS Education Pond Area is presented in Table 2. 
Table 2. Density values of mangrove species found in the Hasanuddin Education Pond Area

\begin{tabular}{|c|c|c|c|}
\hline Station & Mangrove Species & $\begin{array}{l}\text { Number } \\
\text { of Tree } \\
\text { (Ni) }\end{array}$ & $\begin{array}{l}\text { Density } \\
\text { (Ind/m2 } \\
\text { ) }\end{array}$ \\
\hline \multirow[t]{6}{*}{ I } & Avicennia marina & 1 & 0.01 \\
\hline & Rhizophora & 16 & 0,16 \\
\hline & Rhizophora stylosa & 3 & 0,03 \\
\hline & Sonneratia alba & 2 & 0,02 \\
\hline & Total & 22 & 0,22 \\
\hline & Average & & 0,03 \\
\hline \multirow[t]{7}{*}{ II } & Bruguiera & 4 & 0,04 \\
\hline & Ceriops decandra & 4 & 0,04 \\
\hline & Rhizophora & 3 & 0,03 \\
\hline & Rhizophora stylosa & 20 & 0,20 \\
\hline & Sonneratia alba & 11 & 0,11 \\
\hline & Total & 42 & 0,42 \\
\hline & Average & & 0,10 \\
\hline \multirow[t]{7}{*}{ III } & Bruguiera & 4 & 0,04 \\
\hline & Rhizophora & 30 & 0,30 \\
\hline & Rhizophora stylosa & 18 & 0,18 \\
\hline & Rhizophora & 8 & 0,08 \\
\hline & Sonneratia alba & 3 & 0,03 \\
\hline & Total & 63 & 0,63 \\
\hline & Average & & 0,09 \\
\hline \multirow[t]{5}{*}{ IV } & Rhizophora & 5 & 0.05 \\
\hline & Rhizophora stylosa & 46 & 0,46 \\
\hline & Sonneratia alba & 3 & 0,03 \\
\hline & Total & 54 & 0,54 \\
\hline & Average & & 0,09 \\
\hline \multirow[t]{3}{*}{ V } & Rhizophora stylosa & 59 & 0,59 \\
\hline & Total & 59 & 0,59 \\
\hline & Average & & 0,08 \\
\hline
\end{tabular}

From the calculated results of the density value of mangrove species based on tree categories at all stations shows that Rhizophora stylosa has the highest density value when compared to other types. Based on the average density value at each Station, Station I had a density value of $0.03 \mathrm{ind} / \mathrm{m} 2$, Station II had a density value of $0.10 \mathrm{ind} / \mathrm{m} 2$, Stations III and IV had the same density value of $0.09 \mathrm{ind} / \mathrm{m} 2$, Station $\mathrm{V}$ had a density value of $0.08 \mathrm{ind} / \mathrm{m} 2$. The density parameter (Yulianda, 2007), the category for all stations is bad enough for mangrove tourism because the value was between $5-10 \mathrm{ind} / \mathrm{m} 2$.

\section{Environmental Parameters}

Tidal measurements at the research location were at coordinates $4^{\circ} 05^{\prime} .701^{\prime \prime}$ South and $119^{\circ} 36^{\prime}, 684^{\prime \prime}$ East. The measurement results show the type of daily tidal (semi diurnal tide) which is a tide that the rise and the low of tides occur twice that are almost the same height in one day (Wyrtki, 1961). Data on tides was the primary data obtained from measurements at the research location for 39 hours. From tidal data analysis shows that the water level at the research site at the time the highest tide reached $93.00 \mathrm{~cm}$ on the tidal signs while the water level at the lowest ebb was $20.00 \mathrm{~cm}$, indicating that the tidal range obtained was $57.50 \mathrm{~cm}$, the tidal range is in the good category (Yulianda, 2007 ) for the selection of mangrove tourism sites by considering safety and affecting the vertical distribution of mangroves.

The salinity value obtained at the research location from the results of measurements in the field of each station namely Station I had an average salinity value of $31.99 \mathrm{ppt}$, Station II $31.50 \mathrm{ppt}$, Station III 34.62 ppt, Station IV 34.33 ppt and Station V 34.11 ppt. High salinity is found at Station III while low salinity is found at Station II. UNHAS Education Pond Area has tidal conditions that greatly affect salinity in mangrove habitats. Salinity conditions measured in the field were suitable for mangrove growth. This is supported by the opinion (Sultan, 2001) which states that mangrove ecosystems can grow in the range of salinity to $42 \mathrm{ppt}$.

Table 3. Biota found in mangrove forests in the UNHAS Education Pond Area

\begin{tabular}{|c|c|c|c|}
\hline Biota Objects & Latin Names & $\begin{array}{l}\text { Indonesian } \\
\text { Names }\end{array}$ & $\begin{array}{l}\text { English } \\
\text { Language }\end{array}$ \\
\hline \multirow[t]{8}{*}{ Fish } & Mugil sp. & Ikan & Mullet \\
\hline & & Ikan & Mud \\
\hline & $\begin{array}{l}\text { Epinephelus } \\
\text { Bleekeri }\end{array}$ & Kerapu & Grouper \\
\hline & & Lumpur & Fish \\
\hline & Periopthalmus & Ikan & Shod Fish \\
\hline & & Gelodok & \\
\hline & Sphaeramia & Ikan & Cardinal \\
\hline & orbicularis & Capungan & Fish \\
\hline \multirow[t]{4}{*}{ Birds } & Ciconia sp. & Burung & Storks \\
\hline & Egretta & Burung & Small \\
\hline & garzetta & $\begin{array}{l}\text { Kuntul } \\
\text { Kecil }\end{array}$ & $\begin{array}{l}\text { egrets } \\
\text { birds }\end{array}$ \\
\hline & $\begin{array}{l}\text { Halcyon } \\
\text { sancta }\end{array}$ & $\begin{array}{l}\text { Cekakak } \\
\text { suci }\end{array}$ & $\begin{array}{l}\text { Sacred } \\
\text { Petals }\end{array}$ \\
\hline Reptile & Dasia sp. & Kadal & Lizard \\
\hline \multirow[t]{3}{*}{ Crustaceans } & Episesarma & Kepiting & Mangrove \\
\hline & Scylla serrata & $\begin{array}{l}\text { Kepiting } \\
\text { Bakau }\end{array}$ & $\begin{array}{l}\text { Mangrove } \\
\text { Crab }\end{array}$ \\
\hline & $\begin{array}{l}\text { Clibanarius } \\
\text { sp. }\end{array}$ & $\begin{array}{l}\text { Kelomang } \\
\text { Mangrove }\end{array}$ & $\begin{array}{l}\text { Mangrove } \\
\text { Hermit } \\
\text { Crabs }\end{array}$ \\
\hline \multirow[t]{8}{*}{ Molluscs } & Littorina $\mathrm{sp}$ & Siput Laut & Sea Snail \\
\hline & Faunus ater & Siput & $\begin{array}{l}\text { Black } \\
\text { Devil } \\
\text { Snail }\end{array}$ \\
\hline & Terebralia sp. & Siput & Sea Snail \\
\hline & Pila sp. & Keong & Conch \\
\hline & Nerita sp. & Siput & Snail \\
\hline & Gafrarium sp. & Kerang & Scallops \\
\hline & Telescopium & Keong & Mangrove \\
\hline & Telescopium & Bakau & Conch \\
\hline
\end{tabular}




\section{Biota object}

Biota found in mangrove forests in the Unhas Education Pond Area is presented in Table 3. The fish found in the mangrove forest were generally fish caught in a gillnet that had been set at each station. The discovery of mullet fish (Mugil sp.), Sphaeramia orbicularis and mud grouper fish (Epinephelus Bleekeri) were thought to be due to the influence of ponds in the area, while the shod fish (Periopthalmus sp.) were discovered because they are true settlers of the habitat, and its life cycle is in mangrove forests.

Other biota found were birds. Storks (Ciconia sp.) are often seen around mangrove forests because of the large number of small fish and other biota that are their food. Types of small egrets birds (Egretta garzetta), sacred petals (Halcyon sancta) found in mangrove trees as nesting sites, interacting and going out looking for food in the area of the pond around the research site during the morning and evening. In addition to birds, also found one type of reptile, the lizard (Dasia sp.). The reptiles were found while crawling on mangrove trees, above the ground, and swimming.

Other biota that was commonly found in mangrove forests was crustaceans and mollusks. Crustaceans found in the mangrove area of the UNHAS Education
Pond were mangrove crabs (Episesarma sp.), Mangrove crabs (Scylla serrata), and mangrove hermit crabs (Clibanarius sp.). Mollusks found in the mangrove areas of UNHAS Education Pond were (Littorina sp.), (Faunus ater), (Terebralia sp.), (Pila sp.), (Nerita sp), (Gafrarium sp.) And (Telescopium Telescopium). Crustaceans and mollusks were found attached to mangroves and they were in the substrate. Whereas other biota found, such as fish, birds, reptiles, crustaceans and mollusks, the category of biota object parameters in the UNHAS Education Pond Area was good.

\section{Land Conformity Analysis and Concept of Mangrove Education Infrastructure Facilities}

The research is expected to be able to find various levels of land suitability categories for each parameter at each station, then the calculation and assessment of land suitability for mangrove tourism can be obtained so that the results and categories of the concept of suitability of mangrove tourism facilities and infrastructure basically consist of three parts, namely the buffer area, the reception area and activity areas as presented in Table 4 and Table 5.

Table 4. Results of land suitability assessment for the parameters of mangrove ecosystems in the Hasanuddin University Education Pond.

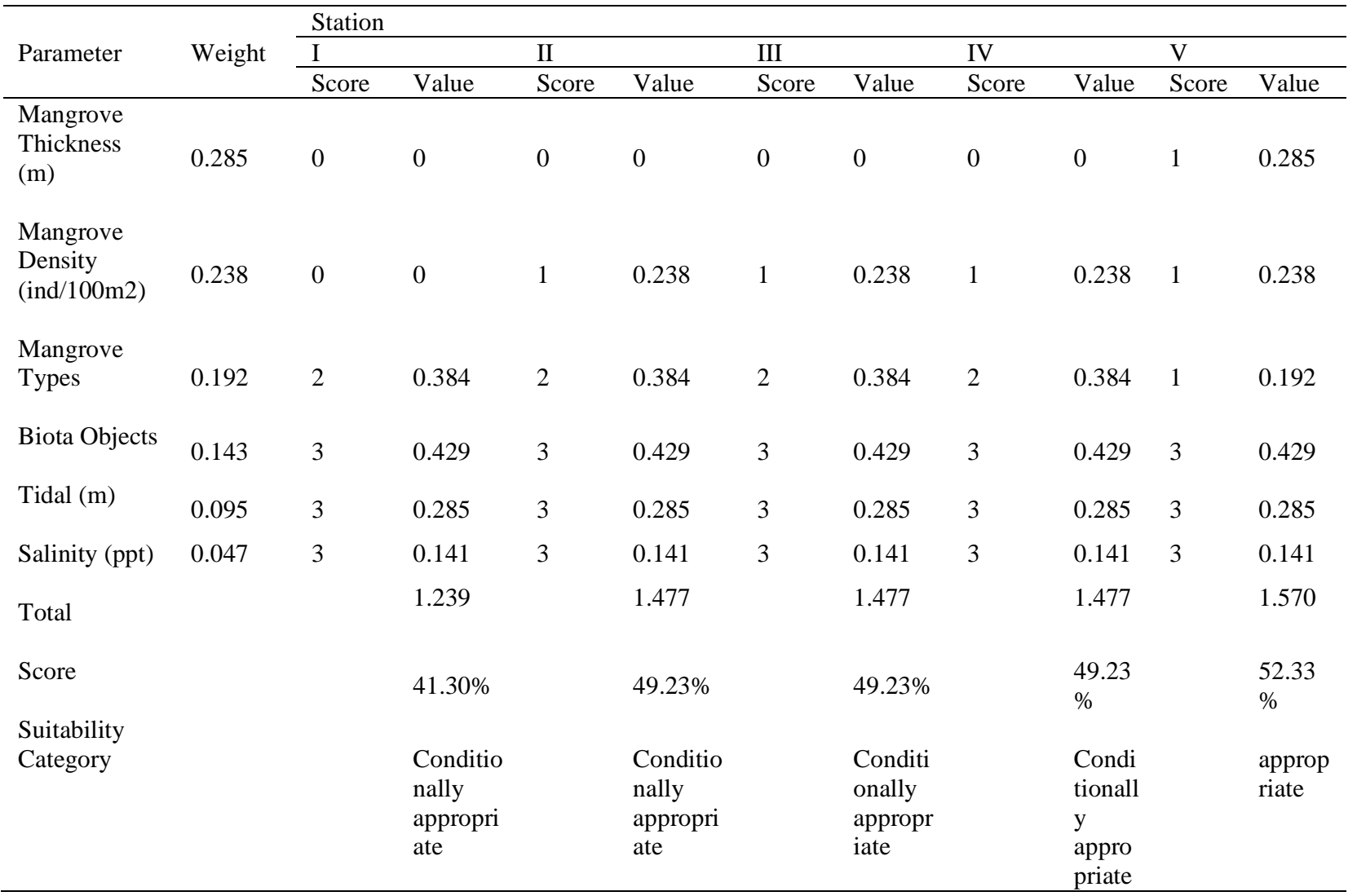

The suitability of the mangrove ecosystems tourism field shows the highest parameter values are the object of biota, tides and salinity, this means the
UNHAS Education Pond Area has the potential to be developed. Suitability value for Station I was $41.30 \%$ with conditional appropriate category supported by 
the value of mangrove species, tides, salinity and good biota objects but the thickness value of mangrove and mangrove density was bad for mangrove tourism, the suitability value of Station II, III and IV was $49.23 \%$ with conditional appropriate category supported by the value of mangrove species, tides, salinity and good biota objects but the value of mangrove density and thickness of mangrove was bad for tourism, the suitability value of Station V was $52.33 \%$ with the appropriate category supported by the value of mangrove thickness, tides, salinity and good biota objects, but the value of mangrove species and mangrove density was bad for mangrove tourism.
Based on the calculation of the land suitability category obtained from the value of each parameter, it can be concluded that the mangrove forest area in the UNHAS Education Pond is a conditionally appropriate category as a mangrove tourism showing that the area needs a development strategy in order to become an appropriate category. The educational tour parameters which were indicators of appropriateness, namely the support of facilities and infrastructure as one of the reference concepts proposed as mangrove tourism areas can be seen in Table 5 .

Table 5. Concepts of the suitability of facilities and infrastructure for mangrove tourism in UNHAS Education Pond Area (Pranatha, 2015)

\begin{tabular}{|c|c|c|c|c|}
\hline Facility & & & & \\
\hline Room & Activities & Facilities & Infrastructure & Availability \\
\hline 1 & 2 & 3 & 4 & Yes $\quad$ No \\
\hline Buffer Area & Park the vehicles & Parking area & $\begin{array}{l}\text { Information Board } \\
\text { Signs }\end{array}$ & Yes \\
\hline $\begin{array}{l}\text { Reception } \\
\text { Area }\end{array}$ & Visitors reception & Reception Room & $\begin{array}{l}\text { Information Board } \\
\text { Souvenir Room } \\
\text { Ticket Counter } \\
\text { Toilet }\end{array}$ & Yes \\
\hline \multirow{7}{*}{$\begin{array}{l}\text { Activities } \\
\text { Area }\end{array}$} & $\begin{array}{l}\text { Fish, Shrimp, Crab } \\
\text { Cultivation }\end{array}$ & $\begin{array}{l}\text { Fish, Shrimp, } \\
\text { Crab Pond Area }\end{array}$ & $\begin{array}{l}\text { Information Board } \\
\text { Boots }\end{array}$ & Yes \\
\hline & Bird watching & Watching Tower & $\begin{array}{l}\text { Information Board } \\
\text { Binocular }\end{array}$ & Yes \\
\hline & $\begin{array}{l}\text { Mangrove Seed } \\
\text { Planting }\end{array}$ & $\begin{array}{l}\text { Planting Area } \\
\text { Deck }\end{array}$ & $\begin{array}{l}\text { Information Board } \\
\text { Mangrove Seed } \\
\text { Boots }\end{array}$ & Yes \\
\hline & Outbound Activity & Area outbound & $\begin{array}{l}\text { Information Board } \\
\text { Security Tools }\end{array}$ & Yes \\
\hline & Canoeing & Floating Deck & $\begin{array}{l}\text { Information Board } \\
\text { Boat } \\
\text { Life jacket }\end{array}$ & Yes \\
\hline & Restaurant & Restaurant & $\begin{array}{l}\text { Dining Room } \\
\text { Toilet }\end{array}$ & Yes \\
\hline & Praying Facilities & Mosque & $\begin{array}{l}\text { Praying Room } \\
\text { Toilet } \\
\text { Boots }\end{array}$ & Yes \\
\hline
\end{tabular}

The availability of facilities and infrastructure for mangrove tourism in UNHAS Educational Pond area is a good category because it has potential tourism objects to be developed. Based on the concept of the suitability level of the facilities and infrastructure obtained, it can be concluded that the educational tourism area can provide a learning to visitors, especially students at the elementary school level, junior high school, senior high school and college, knowing mangroves and interacting directly with the mangrove environment as an effort creating a sustainable region.

\section{CONCLUSION}

Based on the results of the research conducted, several conclusions can be concluded: (1). The content of organic material of dominant mangrove sediments on
Pannikiang Island had insignificant organic matter content of $p>0.05$ between stations that were overgrown with mangroves, while stations that were overgrown with those with no mangroves were significantly different $p<0.05$. The highest value of organic matter content at station 1 was Rhizophora apiculata (32.83) and the lowest organic matter content was at station 4 with no mangroves (2.58\%) (2). Regression test results stated that there was a significant relationship $(p>0.05)$ to the content of sediment organic matter with the density of mangrove species and the correlation coefficient value (r) obtained by 0.594 meaning this value was categorized as having a relationship between the content of organic sediment material with the density of mangrove species. It is recommended that further research be carried out on the relationship of organic matter to the density and closure of the dominant 
mangrove species by taking sediment samples at high tide and ebb on Pannikiang Island, Balusu District, Barru Regency.

\section{REFERENCES}

Anwar, 1984. Language of Journalism and Composition. Jakarta: Pradaya Paramita.

Ardhana, I W. 2002. Development Research Concepts in the Field of Education and Learning. Paper presented at the National Workshop Generation II Development Research Methodology in Education and Learning. (Thesis).

Bahar, A. 2015. Sea Survey Guidelines. Makassar: Masagena Press. Makassar.

Bengen, D.G., 2001. Technical Guidelines for Introduction and Management of Mangrove Ecosystems. Center for Coastal and Ocean Resource Study. Bogor Agricultural Institute. Bogor, Indonesia.

Buckman, H. O. and N. C. Brady. 1982. Soil Science. Gajah Mada University Press. Yogyakarta.

Colin, P.L., and C. Arneson, 1994. Tropical Pacific Invertebrate a Publication of the Coral Reef Research Foundation. Coral Reef Press. California The USA.

Dahuri, R., Rais J, and Ginting. S.P., M.J. 1996. Integrated Management of Coastal and Marine Resources. Pradnya Paramitha, Jakarta

Dharma, B. 1988. Indonesian snails and shells. First part. PT. Means of Graha. Jakarta.

Dharma, B. 1992. Indonesian Snails and Shells. The second part. PT. Means of Graha. Jakarta.

Darmadi, M. W. Lewaru and A.M.A. Khan 2012. Structure of Mangrove Vegetation Community Based on Substrate Characteristics in Muara Harmin Cangkring Village, Cantigi District, Indramayu Regency. Journal of Fisheries and Maritime Affairs. 3 (3): 347 - 358.

English, S., Wilkinson, C., and V. Baker, 1994. Survey Manual for Tropical Marine Resources. Australian Institute of Marine Science. ASEAN-Australia Marine Science Project Living Coastal Resource.

Efriyeldi. 1997. Macrozoobenthos Community Structure and its Relation to the Characteristics of Sediments in Muara Sungai Bantan Tengah Waters, Bengkalis. Postgraduate Thesis of Bogor Agricultural University. 102 things.

Ghufran, M and Kordi, K. 2012. Mangrove Ecosystem Potential, Function and Management. Rineka Cipta. Jakarta.
Gunkel W. 1976. Organic Substrate. Bacteria, Fungy and Blue Green Algae. John Wiley and Sons Inc. New York.

Halidah. 2014. Natural Distribution of Avicennia marina (Forsk) Vierh and Sonneratia alba Smith on the Sand Substrate in Tiwoho Village, North Sulawesi. Indonesian Rehabilitation Forest Journal, 1 (1) 51-58.

Hutabarat, S and S.M. Evans. 1995. Introduction to Oceanography. University of Indonesia Press, Jakarta.

Irwanto, 2006. Fauna Diversity in Mangrove Habitats. Yogyakarta.

Jalil, A.R., M. Lanuru., W. Samad., And M. Hatta (ed). 2015. Sea Survey Guidelines. Makassar: Masagena Press. Makassar.

Kushartono, E W. 2009. Some Bio-Physical Aspects of Soil Chemistry in the Mangrove Area of Banggi Village, Rembang Regency. Department of Marine Sciences. Faculty of Fisheries and Marine Science. Diponegoro University. Semarang.

Kusmana, C. 2002. Mangrove Ecology. IPB Forestry Faculty. Bogor

State Minister for the Environment. 2004. Decree of the Minister of Environment Number 201 of 2004 concerning Standard Criteria and Guidelines for Mangrove Damage. State Minister for the Environment. Jakarta.

Naughton, S. M. 1990. General Ecology. Gajah Mada University press. Yogyakarta.

Noor, Y., R. 2006. Guidance to Introduction of Mangroves in Indonesia. Wetland International - Indonesia Program. Bogor.

Nybakken, J. W. 1988. Marine Biology. An Ecological Approach. Gramedia. Jakarta.

Saru, A. 2013. Revealing the Potential of Green Gold in Coastal Areas. Masagena Press. Makassar

Saru, A., K. Amri, and Mardi. 2017. Connectivity of Mangrove Vegetation Structure with Acidity and Total Organic Material in Sediments in Wonomulyo District, Polewali Mandar Regency. SPERMONDE Journal, 3 (1): 1-6

Yusuf, S., B. Congratulations., K. Amri., A.l. Burhanuddin, and Mashoreng. S. 2016. Condition of Coral Reefs and Related Ecosystems in Liukang Tuppabbiring, Pangkep Regency. Coremap-CTI; Jakarta.

Whtter, J. 1987. The Ecology of Sulawesi. Gajah Mada University Press, Yogyakarta. 